\title{
Increasing Customer Satisfaction through Omnichannel Retailing
}

Sean Jui Hee Ng, Adriana Mohd. Rizal, Haliyana Khalid, Theresa Char Fei Ho and Musli Sahimi

To Link this Article: http://dx.doi.org/10.6007/IJARBSS/v11-i11/11267

DOI:10.6007/IJARBSS/v11-i11/11267

Received: 09 September 2021, Revised: 11 October 2021, Accepted: 30 October 2021

Published Online: 10 November 2021

In-Text Citation: (Ng et al., 2021)

To Cite this Article: Ng, S. J. H., Rizal, A. M., Khalid, H., Ho, T. C. F., \& Sahimi, M. (2021). Increasing Customer Satisfaction through Omnichannel Retailing. International Journal of Academic Research in Business and Social Sciences, 11(11), $696-707$.

Copyright: (c) 2021 The Author(s)

Published by Human Resource Management Academic Research Society (www.hrmars.com)

This article is published under the Creative Commons Attribution (CC BY 4.0) license. Anyone may reproduce, distribute, translate and create derivative works of this article (for both commercial and non-commercial purposes), subject to full attribution to the original publication and authors. The full terms of this license may be seen

at: http://creativecommons.org/licences/by/4.0/legalcode

Vol. 11, No. 11, 2021, Pg. 696 - 707

Full Terms \& Conditions of access and use can be found at http://hrmars.com/index.php/pages/detail/publication-ethics 


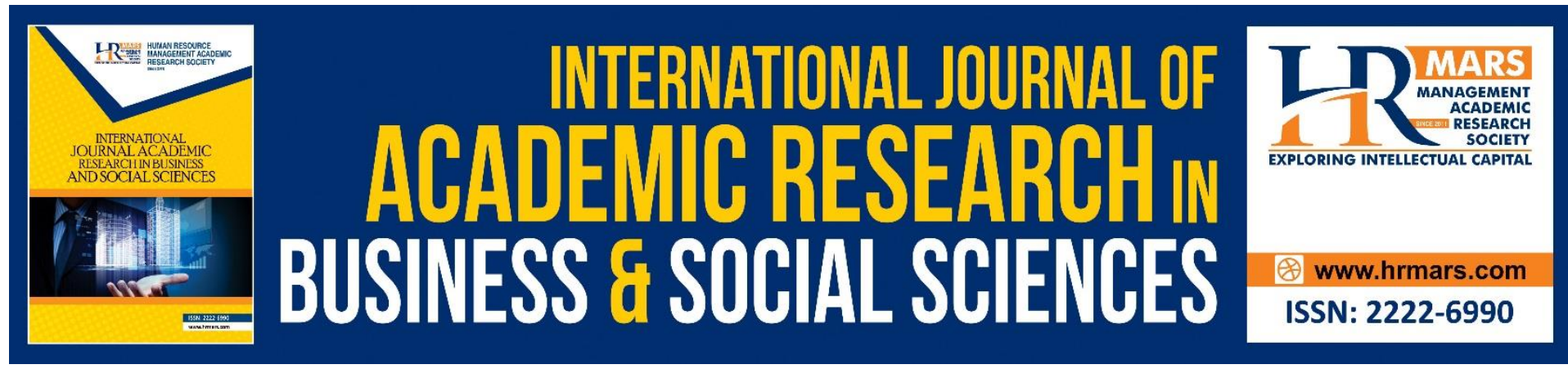

\title{
Increasing Customer Satisfaction through Omnichannel Retailing
}

\author{
Sean Jui Hee $\mathrm{Ng}^{1}$, Adriana Mohd. Rizal ${ }^{2}$, Haliyana Khalid ${ }^{3}$, \\ Theresa C.F. Ho ${ }^{4}$ and Musli Sahimi ${ }^{5}$ \\ 1,2,3,4 Azman Hashim International Business School, Universiti Teknologi Malaysia, Malaysia, \\ 2,3 University of Business and Technology, Jeddah, Saudi Arabia, ${ }^{5}$ Graduate School of \\ Business, Universiti Kebangsaan Malaysia, Malaysia
}

\begin{abstract}
Customer satisfaction is one of the success factors for many retailers. With the widespread use of smartphones worldwide, retailers have adopted many new innovative and disruptive retail business models. Digitalization brings retail business into a new era and has profoundly and positively affected the business' strategy. Retailers strive to provide customers with an easy, smooth, happy, joyful, and relaxed shopping experience. One of the disruptive digital innovations in retailing is Omnichannel Retailing. The ideas are to rejuvenate, revitalize, and increase customer satisfaction during their shopping journey either at the store (offline) or through online shopping platforms. The customer shopping experience is enhanced by providing channels and touchpoints that are emerged during their shopping journey. The objective of this study is to review the customer relationship literature within the context of the omnichannel retailing perspective. This study proposes a conceptual model to understand the factors that increase customer satisfaction through omnichannel retailing.
\end{abstract}

Keywords: Omnichannel, Customer Satisfaction, Convenient, Enjoyable, Comfortable, Trust.

\section{Introduction}

Customer satisfaction is essential for the retailer to maintain its sustainability and profitability. Many world-beating retailers are striving to achieve and exceed customer expectations to increase customer satisfaction levels. Customer satisfaction is a feeling of fun, entertainment, enjoyment, and pleasantness during the shopping journey. According to Azhari and Benett (2015), customer satisfaction is derived from customers' overall experience throughout their shopping journey, from searching products, researching, making a purchase decision, and receiving after-sales service from the retailers. Customer satisfaction is a customer's overall and holistic measurement of products or services in meeting and fulfilling customer expectations. Retailers have attempted many efforts to increase customer satisfaction through an omnichannel retailing strategy. Recently, the usage of digital technologies and processes has enhanced the shopping experience for customers. Advances in Augmented Reality (A.R.), Artificial Intelligence (A.I.), Virtual Reality (V.R.), and Blockchain technology take the customer purchasing experience to new heights (Cai and Lo, 2020). Omnichannel retailing has been extensively introduced into the business model and company 
policy by many retailers such as Walmart, Macy, Amazon, Uniqlo, Zara, and H\&M to enrich customer shopping experience (Klie, 2014; Manion, 2015; McCarthy, 2017; Skrovan, 2017; Waldron, 2018).

According to Manion (2015), one of the biggest retailers in the retail industry, Walmart, has embarked and positioned the company towards omnichannel marketing (Loafman, 2020; Skrohe van, 2017). This strategy has been deployed into Walmart's global strategy plans and embraces in between online and offline channels, with the presence of its 11,000 brick-andmortar stores globally. Walmart U.S announced an overall revenue of $\$ 137.74$ billion in $2 Q$ 2020 (Redman, 2020), up 5.6\% from the previous year, with net sales increased $9.5 \%$ at $\$$ 93.28 billion in the same period. The results attributed to the launching of omnichannel retailing in fully transforming the organization's core competency to integrate its distribution and supply chain nationwide since 2015. Amazon is also exploring an omnichannel strategy to make it become the earth's most customer-centric company (Serrano, 2021). Amazon has optimized its key metrics to create a seamless and holistic shopping experience for its customers across all channels with simultaneously selling channel integration. The strength lies in Amazon's online data collection to provide a personalized purchase experience, respond immediately, and interact with the customers across all channels.

According to Centric Digital (2016), the omnichannel strategy helps to turnover Macy's sales in three-year in a row. The 150-year-old department store has made a turnaround of its fortune through its digital transformation since 2010. Through a holistic omnichannel strategy implanted into Macy's operation and workforce, Macy successfully integrated and synthesized customers' shopping experience into a new digital exciting experience (Lauchlan, 2019; Malinowska, 2019). Similarly, a Japan-based fast fashion designer, manufacturer, and retailer, Fast Retailing Co., has developed its omnichannel strategy to increase customer satisfaction. With the slogan made for all, the company with more than 834 active stores in 2017 worldwide emerged as an online player. Chairman Yanai invested in apps to rival other online retailers to collect data on customers' purchase history and preferences to create an authentic personalized omnichannel customer experience for the Uniqlo system to recommend clothes that match customers' needs (aCommerce, 2017; WARC, 2018).

Another world giant clothing retailer Inditex (Zara) has reported its 1Q 2019 net sales to increase $5 \%$ at $\$ 10.18$ billion compared to the previous year, which contributed by $12 \%$ online sales, but $88 \%$ was from the physical store. The chairman and CEO Isla commit to providing customer-driven quality fashion and focusing on digital transformation at its integrated store and online sales platform by reaching customers using online and offline technologies and touchpoints (Abano, 2019). In H\&M 2017 Annual Report, the company announced the innovation to integrate its brick-and-mortar store with the digital channels to provide the customer with an easy, happy, convenient, and inspiring shopping experience. The unique combination of H\&M's digital competency and its physical store has brought $\mathrm{H} \& \mathrm{M}$ to make a quantum leap to provide its customers with a unique, memorable, seamless, fantastic shopping experience (H\&M Annual report, 2017).

A recent report of e-commerce sales published by Statista, "Global retail e-commerce sales 2014-2024" (Chevalier, 2021), reveals the overwhelming development of e-commerce worldwide. Global e-commerce growth started in 2014, while digitalization has intensely introduced to the retail market, where it records a total sale of \$1.34 trillion U.S. dollars worldwide. In just three years later, in 2017 , the sales have leaped to $\$ 2.38$ trillion U.S. dollars. In 2020, the e-commerce sales records worldwide reached $\$ 4.21$ trillion, an increase of $170 \%$. With the impact of the pandemic Covid-19, experts expect online e-commerce to boost up to 
nearly 5 trillion U.S. dollars in 2021. In Malaysia, the e-commerce market is worth the U.S. \$ 4.3 billion in 2020 and expects to achieve the U.S. $\$ 8.1$ billion by the year 2024 (Aprameya, 2020). Another research conducted by GlobalData (2020) has shown that Malaysia's ecommerce market is registered a growth of $24.7 \%$ compared to 2019 . The increase is mainly attributed to the Covid-19 pandemic that many consumers' purchasing behavior has switched from offline to online, which has accelerated the growth of e-commerce in Malaysia. The study has predicted that the e-commerce market to achieve MYR 51.6 billion by 2024. A study conducted by Morgan (2020) discloses the strength of Malaysia's e-commerce, where Malaysia has a population of nearly 31.6 million, GDP recorded at $\$ 314.7$ billion, with an ecommerce value of almost $\$ 4$ billion.

Internet penetration at $80.1 \%$, and smartphone penetration at $63.9 \%$, which are the highest among Southeast Asia countries, have tremendously contributed to the development of ecommerce in the country. The government has further introduced National E-Commerce Strategic Roadmap (The Malaysia Reserve, 2017) to outline and promote the e-commerce industry to achieve RM170 billion by 2020 , growing at $20.8 \%$. Nevertheless, only a few major retailers in Malaysia have embraced omnichannel retailing and integrated their online businesses with physical stores to leverage its strength to increase sales by increasing customer satisfaction. This paper highlights the critical factors for the successful incorporation of an omnichannel strategy. Therefore, this study is significant in discussing the factors affecting omnichannel retailing in Malaysia from customers' perception of increasing satisfaction from convenience, enjoyment, comfort, and trust.

\section{Literature Review \\ Customer Satisfaction}

Customer satisfaction measures how a company's product or service meets or surpasses customers' needs and expectations. According to Widagdo and Roz (2020), customer satisfaction is measured by the customers' pleasantness or dreadfulness experience after purchasing a product and/or service. Successful synchronizing and integrating the physical store and online channels play an important role in the omnichannel strategy to ensure and increase customer satisfaction and loyalty to the brand (Kumar and Reinartz, 2016). Personalized services, offerings, and advertisements are key factors that improve customer service experience and customer satisfaction (Tyrvainen et al., 2020), which then creates positive word-of-mouth and increases customer return and purchase intention. Cook (2014) suggests retailers embrace omnichannel retailing to increase customer satisfaction and merge their online and offline environment to give customers a unified, seamless, and pleasant shopping experience (Briel, 2018) at the physical store or online. Hedonic motivation and experience directly create positive value to increase customer satisfaction (Widagdo and Roz, 2020; Tyvainen et al., 2020). Retailers are duty-bound to nurture and cultivate an online relationship with the customers. Such relationships facilitated by new technologies, social media, and big data are critical to managing and influencing customers in providing a personal experience for increasing customer satisfaction (Steinhoff et al., 2018).

Past researchers have discussed widely the factors that affect customer satisfaction in omnichannel retailing, namely convenient, enjoyable, comfortable feeling and level of trust during the shopping journey and experience (Chopra, 2015; Klie, 2014; Sengupta, 2014; Sopadjieva et al., 2017). Many new technologies, especially smartphones and mobile apps, have instantly facilitated customers' searching process about products or services. Simultaneously, customers may receive online offers and e-voucher to increase their 
purchase intention (Juaneda-Ayensa et al., 2016). All channels are merged into a single platform for customers to complete their transactions with simply few fingers clicks. Omnichannel customers who fully engage with digital and social media feel more convenient and enjoyable to interact with retailers instantly (Zhang et al., 2018) through social media channels (Pantono and Viassone, 2015). Notably, retailers with physical stores and online channels better serve their customers (Grewal et al., 2017). However, many customers still prefer to interact with the sales representatives at the physical store (Margetis et al., 2019). In this context, retailers need to improve and enhance their customers' service quality to serve better omnichannel customers who are more prepared and knowledgeable about the products (Azhari, 2015; Sengupta, 2014).

\section{Omnichannel Retailing}

During the past decade, many researchers have claimed that omnichannel retailing is one of the successful recipes in increasing customer satisfaction and retailers' profitability (Grewal et al. 2017; Hubner et al. 2015; Sopadjieva et al. 2017). "Omni" was abstracted from a Latin prefix that means all and every (Briel, 2018). Omnichannel retailing prioritizes customer experience by combining different channels, merging online and offline, brick-and-mortar and mobile devices (Verhoef et al., 2015) into a single platform to enrich customers' shopping experience. Hubner et al (2015) discover that customers have more opportunities to purchase using omnichannel retailing, breaking down the barrier of the online and offline environment to offer the customer a seamless shopping experience. Customers demand flexibility in product or service searching (Sengupta, 2014) and freedom to use different channels (Lazaris and Vrechopoulos, 2014; Chopra, 2015) to compare the quality and price, place their order online, and choose delivery options. All those activities are offered in omnichannel for customers' convenience.

Zhang et al (2018) reveal that with the fast and rapid development of e-commerce, many world-beating retailers are digitally using all sorts of channels to reach out to customers and satisfy customers' expectations. The process involves simplifying and integrating all the channels in physical stores, in-store catalogs, internet kiosks, interactive tablets, and call centers to provide customers with a convenient, enjoyable, and comfortable shopping experience. Grewal et al (2017) assert that customers have all sorts of information about the products and services. As such, retailers need to provide valuable information to the customers to help them decide. Omnichannel customers expect the sales representatives at the physical store to be more knowledgeable (Sengupta, 2014) to help them make purchasing decisions. Chopra (2015) asserts that the partnership of brick-and-mortar stores and online retailers results in a win-win business model. The convenience and flexibility of the omnichannel enhance customer shopping experience that would increase customer satisfaction.

\section{Factors Affecting Customer Satisfaction in Omni Channel Retailing Convenience}

Convenience is defined as a favorable, comfortable, and easy way to use a product or service to suit customers' needs or expectations with the least difficulty (Cook, 2014; Grewal et al., 2017; Sopadjleva, 2017; Zhang, 2018). Omnichannel customers expect retailers to provide them with the information they are looking for about the products in a very convenient method anytime and anywhere (Cook, 2014) and further offer them quality products and/or services. Innovation of new digital technology and devices (Grewel et al., 2017) such as mobile 
apps and smartphones has changed the business model that benefits retailers and customers. Retailers can reach and respond to their customers instantly and engage with them at a meager cost and more efficient way than ever before. A new form of retail business is to strengthen the application of omnichannel technologies inside the physical store (Margetis et al., 2019) with a digital and online transaction using interactive kiosks, tablets, and interactive walls to complete their purchase (Azhari, 2015).

Grewal et al (2017) also reveal that many retailers integrate new technologies to facilitate customers' decision-making process in which conveniences and personalization increase the purchase intention (Huang et al., 2019) and loyalty. Furthermore, channel integration is important (Gao and Su, 2017) to positively influence customers' positive word-of-mouth (Lee et al., 2018). However, retailers are required to upgrade their system to reflect on their business scale and strategy in meeting customers' expectations on different products (Sengupta, 2014). Process consistency positively affects customers' commitment and engagement with a retailer to purchase online or offline (Huang et al., 2019). Consumer interaction with social media is a trend for retailers to grasp the golden opportunity to stay connected and interact instantly with consumers. Social media have provided platforms for people to connect and network with other people worldwide, gather information (Grewel et al., 2017), share their views, and review feedback from others easily.

\section{Enjoyable}

Retailers provide an enjoyable shopping experience to their customers with fun, amusing, entertaining, and pleasing elements. A pleasant experience in customers' shopping journeys is an important characteristic that leads to customer satisfaction (Herhausena et al., 2015; Verhoef et al., 2015). Alexander and Cano (2019) emphasize the importance of pre-designing the retail environment to enhance the customers' shopping experience. Such design should include the environment as a fun place for the customers to connect with others and provide cultural, community, and educational events. Such an environment creates a place full of fun and excitement, exciting activities, and events for customers involvement. Retailers are suggested to embrace omnichannel retailing into their strategic planning to provide a pleasurable shopping experience (Sopadjieva et al., 2017) in their physical stores with various digital channels. Such a strategy may increase customers' satisfaction and differentiate from their competitors and leverage their physical store as an asset to rival those online-only retailers, such as Amazon, Lazada, and Taobao. Shi et al (2019) reveal that channels integration, consistency, and connectivity have positively influenced customers perceived pleasant compatibility.

On the other hand, Verhoef et al (2015) assert that it is important for retailers to integrate all channels into one channel to provide a pleasant, easy, and smooth shopping experience for their customers. Retailers need to coordinate different channels and touchpoints used by both customers and retailers and be consistent, interchangeable, and simultaneous at any time to serve the customers (Tyrvainen et al., 2020). Cook (2014) reveals that customers expect and demand retailers to provide a pleasant environment to undertake product search and purchase at the time and place that suits them.

\section{Comfortable}

Generally, customers seek a more relaxed, easy, and calm mind when shopping at the stores. Compared to the past generation, customers have access to many technologies during the shopping period (Cook, 2014). Technology enables them to buy products from their comfort 
place and leisure time (Azhari, 2015) using handheld devices. Xu et al. (2019) stated that when customers are familiar and feel easy with one channel, their perceived risks are relatively low, resulting in high loyalty and preferences for using the same channel. However, many customers still prefer to interact with the sales representative (Azhari and Benett, 2015; Grewel et al., 2017) at the counter, making them feel easy and secure. Thus, retailers need to enhance and improve the service quality, competency, and knowledge of the staff at the physical store to serve the customers better and make them feel contented. Such happy customers increase customer satisfaction and intention to purchase decisions (Sengupta, 2014).

\section{Trust}

Trust is a strong belief and confidence of customers towards someone and something. In this context, it is the customer's confidence in the retailers and products they provide. Technology innovation in omnichannel retailing provides retailers with a platform to connect with their customers and increase customers' confidence (Grewel et al., 2017). Xu et al (2019) claim that channel transparency and uniformity among the channels provided affect customers and reduce their perceived risk. Xu et al (2019) also discovered that when the hassle and cost for returning a product to the retailer are high and expensive, a customers' loyalty drops.

According to Cook (2014), customers tend to purchase products online which do not need much concern regarding the products' texture, apparent and tactile aesthetic feel. However, it is more challenging for retailers when it comes to the products that customers are apt to have a more physical approach when they intend to buy. Studies on customers behavior (Sengupta, 2014; Sopadjleva et al., 2017) have disclosed that customers can easily search and survey the product online or at a retail store before they decide to buy. Therefore, the customers feel more confident to make a purchase online with the retailers whom they trust. Customers who felt empowered in decision-making towards purchasing the product also further escalated their perceived trust and satisfaction (Zhang et al., 2018) and increased their purchasing intention with the same retailers. The retailer who fulfills and delivers what customers order is deemed important and plays an essential role in omnichannel retailing to upsurge customers' confidence and satisfaction with the retailer (Wollenburg et al., 2018).

\section{Conceptual Framework}

Many factors affected customers' satisfaction with omnichannel retailing. Two theories underpin the study's conceptual framework (Figure 1). First, Stimulus-Organism-Response (SO-R) Motivational Psychology theory (Woodworth, 1918) states that the stimulus agent causes and provokes different effects and responses from an individual towards the stimulus. Second, Maslow's Hierarchy of Needs Theory (Maslow, 1943) introduces the five-tier model of human needs presented in a pyramid shape. At the bottom are physiological needs, safety needs, love/belonging needs, esteem needs, and self-actualization needs. The Maslow theory claims the needs at the lower down in the hierarchy must be satisfied before a person can attend to the needs on the higher level. Maslow stated that humans are motivated to pursue needs, and some needs take precedence over others. Therefore, to increase customer satisfaction, retailers are urged and required to discuss, deliberate, examine, and justify the factors to promote customer response. Customers' needs and expectations follow a hierarchal sequence to be fulfilled from the bottom of the physiological needs to the top selfactualization during their shopping experience. In this study, the needs of the customer 
include convenience, enjoyable, comfortable and trust that are eventually affected customers' satisfaction in omnichannel retailing, exhibited as follows: -

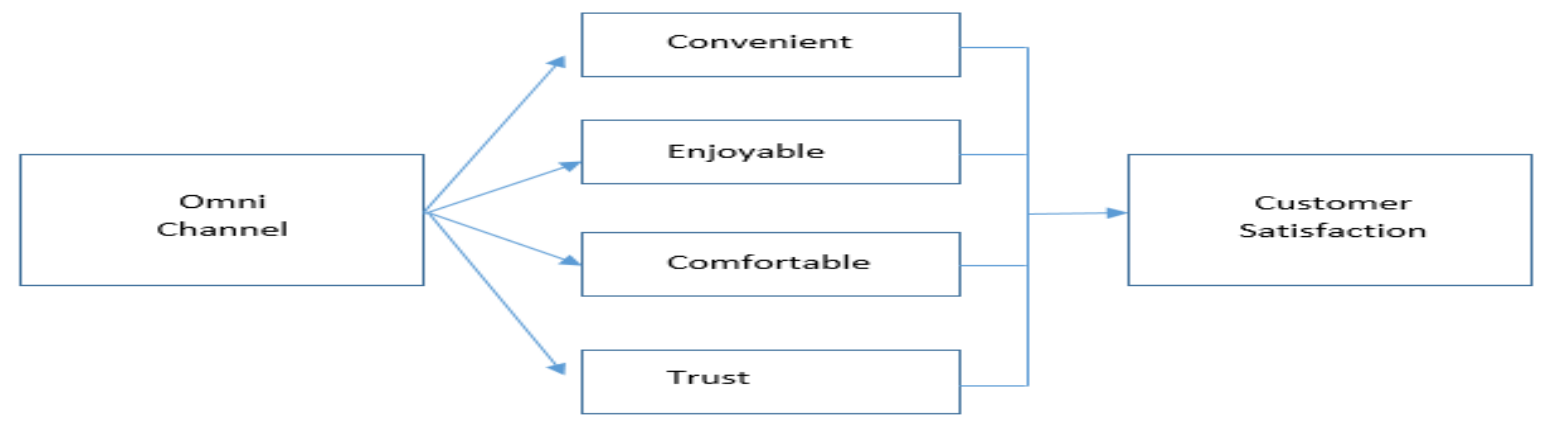

(Source: Chopra 2015; Cook 2017; Grewal 2017; Jamila 2015; Sengupta 2014; Sopadjleva 2017; Zhang 2018)

\section{Figure 1: Factors affecting customer satisfaction in Omni Channel Retailing}

\section{Conclusion and Future Research}

Past research has discussed and focused on fulfilling customers' expectations and needs to increase customer satisfaction. However, the focus of the study is on increasing customers satisfaction using omnichannel retailing. Ultimately, the study summed up the success factors for retailers to improve customer satisfaction in omnichannel retailing.

The study is important to managerial practices to understand the critical factors that increase customers' satisfaction in omnichannel retailing. The study asserts that four aspects, namely convenient, enjoyable, comfortable, and trust, play important roles in improving customer satisfaction. The study synchronizes and synergizes the importance of combining customer experience with digital transformation in the retail world to fortify and consolidate the company's core competency. By embracing an omnichannel retailing strategy, retailers can provide goods and services that surpass customers' expectations. It has integrated the four success factors into its business strategy to improve customers' satisfaction. The result is to provide customers with a straightforward, simple, seamless, no friction and difficulty and a happy, enjoyable, relaxed, and safe shopping experience that has ultimately created a winwin-win benefits for everyone that develops and enhances the ecosystem for the business. First, customers have saved more time and effort on shopping but can get more value and quality products and services they want to purchase through omnichannel retailing. For instance, customers appreciate real-time promotion information and e-voucher from the retailer to enjoy the discount and benefit. Furthermore, with instant chat/call messages, customers can receive instant feedback from the product retailers with easy access to the services center. The secured online e-banking and e-wallet service ensure the online payment process is safe. Second, from retailers' perspectives, they can gain more return customers with high loyalty of the brand and stickiness to the retailers. These loyal customers become valuable assets for the brand. They will introduce and recommend more customers to the retailers thru good word-of-mouth and positive reviews on social media where the impacts are powerful and influential in the digital world. Moreover, with the big data collected from loyal customers of their shopping behavior and preferences through omnichannel, retailers can provide personalized shopping experiences and recommendations to each customer to increase their satisfaction. And last, both customers and retailers can win the last battle in the retail world ecosystem, which they support the growth of each other in gaining 
sustainability. Through rapport, mutual trust between both parties builds a long-term harmonious relationship that nurtures and nourishes business development in the future. Last, the study is significant as it identifies the factors that affect customers' satisfaction in omnichannel retailing in Malaysia. Retailers could apply the factors based on customers' perspectives and expectations to increase customers' satisfaction.

\section{References}

Abano, J. (2019). Zara owner Inditex's omnichannel strategy helps boost sales. Retrieved from: https://insideretail.com.au/news/zara-owner-inditexs-omnichannel-strategyhelps-boost-sales-201906

Acommerce. (2017). Uniqlo's Bullish Omnichannel Retail Strategy. Retrieved from: https://ecommerceiq.asia/eiq-brand-series-uniqlo-omnichannel/

Alexandra, B., Cano, M. B. (2019). Store of the future: Towards a reinvention and reimagination of physical store space in an omnichannel context. Journal of Retailing and Consumer Services, 55. 101913. https://doi.org/10.1016/j.jretconser.2019.101913

Aprameya, A. (2020). Ecommerce in Malaysia: Growth, trends \& opportunities. Retrieved from: https://www.capillarytech.com/blog/capillary/ecommerce/ecommerce-inmalaysia-growth/

Azhari, J. E., Benett, D. (2015). Omni-channel customer experience: An investigation into the use of digital technology in physical stores and its impact on consumers' decisionmaking process. XXIV AEDEM International Conference.

Briel, F. (2018). The future of omnichannel retail: A four-stage Delphi study. Technological Forecasting \& Social Change. DOI: 10.1016/j.techfore.2018.02.004

Cai, Y. J., Lo, C. K. Y. (2020). Omni-channel management in the new retailing era: A systematic review and future research agenda. International Journal of Production Economics, 229. https://doi.org/10.1016/j.ijpe.2020.107729

Centric Digital. (2016). How Macy's implemented a Successful Omnichannel Approach. Retrieved from: https://www.centricdigital.com/blog/how-macys-implemented-asuccessful-omnichannel-approach

Chevalier, S. (2021). Global retail e-commerce sales 2014-2024. Statista. Retrieved from: https://www.statista.com/statistics/379046/worldwide-retail-e-commerce-sales/

Chopra, S. (2015). How omnichannel can be the future retailing. Journal of the Indian Institute of Management Calcutta, Springer; Indian Institute of Management Calcutta, vol. 43(2), 135-144. DOI: 10.1007/s40622-015-0118-9

Cook, G. (2014). Customer experience in the omnichannel world and the challenges and opportunities this presents. Journal of Direct, Data and Digital Marketing Practice. 15, 262-266. DOI:10.1057/DDDMP.2014.16

Gao, F., Su, X. (2017). Omnichannel retail operations with buy-online-and-pick-up-in-store. Management Science, 63(8), 2478-2492. http://dx.doi.org/10.1287/mnsc.2016.2473

Globaldata. (2020). Covid-19 accelerates e-commerce growth in Malaysia. Retrieved from: https://www.globaldata.com/covid-19-accelerates-e-commerce-growth-malaysiasays-globaldata/

Grewal, D., Roggeveena, A. L., Nordfält, J. (2017). The future of retailing. Journal of Retailing, 93(1), 1-6. https://doi.org/10.1016/j.jretai.2016.12.008

H\&M Annual Report. (2017). Retrieved from: https://hmgroup.com/wpcontent/uploads/2020/10/Annual-Report-2017.pdf 
Herhausena, D., Binderb, J., Schoegel, M., Herrmann, A. (2015). Integrating bricks with clicks: Retailer-level and channel-level outcomes of online-offline channel integration. Journal of Retailing, 91(2), 309-325. http://dx.doi.org/10.1016/j.jretai.2014.12.009

Huang, E. Y., Lin, S. W., Cheng, K. T. (2019). How does omnichannel integration quality affect consumers' stickiness intention? Electronic Marketing. DOI: 10.24251/HICSS.2019.573

Hübner, A., Kuhn, H., Wollenburg, J. (2015) Last-mile fulfillment and distribution in omnichannel grocery retailing. International Journal of Retail \& Distribution Management, 44(3), 228-247. http://dx.doi.org/10.1108/IJRDM-11-2014-0154

Morgan, J. P. (2021). E-commerce payments trends: Malaysia, Malaysia e-commerce insights. Retrieved from:

https://www.jpmorgan.com/merchantservices/insights/reports/malaysia

Juaneda-Ayensa, E., Mosquera, A., Sierra Murillo, Y. (2016). Omnichannel customer behavior: Key drivers of technology acceptance and use and their effects on purchase intention. Front. Psychol., https://doi.org/10.3389/fpsyg.2016.01117

Klie, L. (2014). Walmart's omnichannel strategy keeps it on top. CRM Magazine and SmartCustomerService.com. Retrieved from:_https://www.destinationcrm.com/

Kumar, V., Reinartz, W. (2016). Creating Enduring Customer Value. Journal of Marketing, AMA/MSI Special Issue, 80, 36-68. DOI: 10.1509/jm.15.0414

Lauchlan, S. (2019). The omnichannel transformation at Macy's is finally working, just as Trump's China trade war comes along to complicate things. Retrieved from: https://diginomica.com/omni-channel-transformation-macys-finally-working-justtrumps-china-trade-war-comes-along

Lazaris, C., Vrechopoulos, A. (2014). From multichannel to omnichannel retailing: Review of the literature and calls for research. Conference: 2nd International Conference on Contemporary Marketing Issues, (ICCMI). Athens, Greece.

DOI:10.13140/2.1.1802.4967

Lee, Z. W. Y., Chan, T. K. H., Chong, A. Y. L., Thadani, D. R. (2018). Customer engagement through omnichannel retailing: The effects of channel integration quality. Industrial Marketing Management, 77, 90-101.

https://doi.org/10.1016/j.indmarman.2018.12.004

Loafman, J. (2020). Choice and convenience: Omnichannel around the world, today and into the future. Retrieved from: https://corporate.walmart.com/newsroom/2020/12/09/

Malinowska, R. (2019). Macy's reinvents the customer experience. Retrieve from: https://pathtopurchaseiq.com/macys-reinvents-customer-experience

Manion, J. (2015) Walmart positioned to drive omnichannel marketing in global retailing. Retrieved from: https://martech.org/walmart-positioned-drive-omni-channelmarketing-global-retailing/

Margetis, G., Ntoa, S., Stephanidis, C. (2019). Smart Omni-Channel Consumer Engagement in Malls. Springer, pp. 89-96, 2019. https://doi.org/10.1007/978-3-030-23525-3_12

Maslow, A. (1943). Maslow's Hierarchy of Needs. Retrieved from: https://www.simplypsychology.org/maslow.html

McCarth, A. (2017). Omnichannel 2017: Amazon and Walmart make moves. Digital and physical worlds continue to mix and match", Retail \& E-commerce. Retrieved from: https://www.emarketer.com/Article/Omnichannel-2017-Amazon-Walmart-MakeMoves/1015000

Pandey, P., Pandey, M. M. (2015). Research Methodology: Tools and Techniques. Romania, European Union: Bridge Center. Retrieved from: 
https://www.euacademic.org/BookUpload/9.pdf

Pantano, E., Viassone, M. (2015). Engaging consumers on new integrated multichannel retail settings: Challenges for retailers. Journal of Retailing and Consumer Services, 25, 106114. https://doi.org/10.1016/j.jretconser.2015.04.003 -platform/

Rajasekar, S., Philominathan, P., Veerapadran, C. (2013). Research Methodology. India: ResearchGate. Retrieved from: https://www.researchgate.net/publication/2174858

Redman, R. (2020). Omnichannel efforts lift Walmart in the second quarter. Retrieved from: https://www.supermarketnews.com/retail-financial/omnichannel-efforts-liftwalmart-second-quarter

Robert, K. Y. (2011). Qualitative Research from Start to Finish. New York: The Guilford Press. Sengupta, M., Sengupta, N. (2014). Omni-channel retailing: Enriching buyers experience. Asian Journal of Research in Marketing, 3(6), 214-222.

Serrano, S. (2021). What Amazon teaches us about omnichannel strategy in 2019. Retrieve from https://www.barilliance.com/amazon-omnichannel-strategy/

Shi, S., Wang, Y., Chen, X. Z., Zhang, Q. (2019). Conceptualization of omnichannel customer experience and its impact on shopping intention: A mixed-method approach. International Journal of Information Management, 50, 325-336. https://doi.org/10.1016/j.ijinfomgt.2019.09.001

Skrovan, S. (2017). Why Walmart's focus on grocery pickup is a sound strategy. Retrieved from: https://www.grocerydive.com/news/grocery--why-walmarts-focus-on-grocery -pickup-is-a-sound-strategy/534622/

Sopadjieva, E., Dholakia, U. M., Benjamin, B. (2017). A study of 46,000 shoppers shows that omnichannel retailing works. Harvard Business Review. Retrieved from: https://hbr.org/2017/01/a-study-of-46000-shoppers-shows-that-omnichannelretailing-works

Steinhoff, L., Arli, D., Weaven, S., \& Kozlenkova, I. V. (2018). Online relationship marketing. Journal of the Academy of Marketing Science, 47, 369-393. https://doi.org/10.1007/s11747-018-0621-6

The Malaysia Reserve, (2017). Retail sales to thrive on the omnichannel platform. Retrieved from: https://themalaysianreserve.com/2017/04/03/retail-sales-to-thrive-onomnichannel

Tyrvainen, O., Karjaluoto, H., Saarijarvi, H. (2020) Personalization and hedonic motivation in creating customer experiences and loyalty in omnichannel retail. Journal of Retailing and Consumer Services. 57. https://doi.org/10.1016/j.jretconser.2020.102233

Verhoef, P. C., Kannan, P. K., Inman, J. J. (2015). From multi-channel retailing to omnichannel retailing. Journal of Retailing, (xxx, 2015). DOI: 10.1016/j.jretai.2015.02.005

Waldron, J. (2018) How Walmart is leading the omnichannel strategy charge. Retrieved from: https://etailwest.wbresearch.com/blog/how-walmart-is-leading-the-omnichannelcharge

WARC. (2018). UNIQLO puts omnichannel experience ahead of price. Retrieved from: https://www.warc.com/newsandopinion/news/uniqlo-puts-omnichannelexperience-ahead-of-price/41354

Widagdo, B., Roz, K. (2020). Hedonic shopping motivation and impulse buying: The effect of website quality on customer satisfaction. Journal of Asian Finance, Economics, and Business. 8 (1). Doi : 10.13106/jafeb.2021.vol8.no1.395 
Wollenburg, J., Holzapfel, A., Hubner, A., Kuhn, H. (2018). Configuring retail fulfillment process for omnichannel customer steering. International Journal of Electronic Commerce, 22(4). https://doi.org/10.1080/10864415.2018.1485085

Woodworth, R. S. (1918). Dynamic psychology: Stimulus-organism-response (S-O-R). Retrieved from: https://www.newworldencyclopedia.org/entry/Robert_S.

Xu, X., Jonathan, E., Jackson. (2019). Examine customer channel selection intention in the omnichannel retail environment. International Journal of Production Economics. 208( 434-445). https://doi.org/10.1016/j.ijpe.2018.12.009

Zhang, M., Ren, C. S., Wang, A., He, Z. (2018). The impact of channel integration on consumer responses in omnichannel retailing: The mediating effect of consumer empowerment. Electronic Commerce Research and Applications. 28, (181-193).

https://doi.org/10.1016/j.elerap.2018.02.002 